ECOLOGICA, Vol. 28, No 103 (2021), 410-416

https://doi.org/10.18485/ecologica.2021.28.103.11

Оригинални научни рад

УДК: 338.486:[616.98:578.834

\title{
Финансирање пројеката подршке хотелијерству и туризму у време пандемије COVID-19
}

\section{Financing support projects for hotel industry and tourism during the COVID-19 pandemic}

\author{
Адриана Јовић Богдановић ${ }^{1 \star}$, Милан Јанковић ${ }^{2}$, Милан Радосављевић \\ 1,2,3Универзитет Унион - Никола Тесла, Факултет за пословне студије и право, Београд, Србија / \\ Union - Nikola Tesla University, Faculty of Business Studies and Law, Belgrade, Serbia \\ *Аутор за преписку / Corresponding author
}

Рад примљен / Received: 09.07.2020, Рад прихваћен / Accepted: 22.07.2021.

\begin{abstract}
Сажетак: Децембра 2019. године проглашена је пандемија COVID-19 чије су последице за читаво човечанство изузетно велике. Последице се огледају у великом броју оболелих и преминулих, "закључавању" читавих градова и држава, оптерећењу здравствених система, али и по свом утицају на поједине привредне гране. Међу теже погођеним гранама свакако су туризам и хотелијерство. У намери да се смањи ширење вируса, чак су се и државе које остварују значајан приход од туризма и хотелијерства, попут Италије и Грчке, определиле за забрану доласка страних држављања у ове земље у сврхе туристичких посета. Ситуација је била иста и у Србији која, иако у драстично мањој мери, одређени проценат прихода остварује од боравка страних туриста. Све ово утицало је на нормално функционисање и опстанак свих појединаца који су пословали у овом сектору. У сврху помоћи овом сектору и Влада Републике Србије предузела је одређене мере. Примарно је било омогућити хотелијерима и другим лицима запосленим у туризму опстанак, али и одржати број запослених у овим секторима на нивоу пре пандемије, или бар на приближно истом нивоу. У том циљу донешен је низ уредби. Једна група уредби подразумевала је одлагање пореских обавеза, док се друга група уредби односи на директну новчану помоћ. У тренутку писања овог рада туризам и хотелијерство још увек нису ни близу повратка на претходни ниво, а тек остаје да се види и пуна учинковитост мера фринансијске подршке усмерених у туризам и хотелијерство Србије услед пандемије COVID-19.
\end{abstract}

Кључне речи: туризам, хотелијерство, COVID-19, фринансијска подршка угроженим секторима, pandemija, uticaj.

\begin{abstract}
In December 2019, the COVID-19 pandemic was declared, the consequences of which are extremely great for all of humanity. The consequences are reflected in the large number of sick and deceased, the "locking" of entire cities, the burden on health systems, but also in its impact on certain industries. The pandemic did not affect everyone equally, and tourism and hotel industry are certainly among those hardest hit. In order to reduce the spread of the virus, even countries that generate significant income from tourism and hotel industry, such as Italy and Greece, have decided to ban the arrival of foreign nationals in these countries for the purpose of tourist visits. The situation was the same in Serbia, which, although to a drastically smaller extent, generates a certain percentage of income from the stay of foreign tourists. All this affected the normal functioning and survival of all individuals who operated in this sector. In order to help this sector, the Government of the Republic of Serbia has taken certain measures. The primary goal was to enable hoteliers and other people employed in tourism to survive, but also to keep the number of employees in these sectors at the level before the pandemic, or at least at approximately the same level. One group of regulations implied deferral of tax liabilities, while the other group of regulations referred to direct financial assistance. At the time of writing, tourism and hotel industry are still not even close to returning to the previous level, and the full effectiveness of financial support measures aimed at tourism and hotel industry in Serbia due to the COVID-19 pandemic remains to be seen.
\end{abstract}

Keywords: tourism, hotel industry, COVID-19, financial support to vulnerable sectors, pandemic, impact.

\footnotetext{
${ }^{1}$ orcid.org/0000-0003-3201-5541, e-mail: adrianabogdanovic86@gmail.com

${ }^{2}$ orcid.org/0000-0001-7286-5845, e-mail: milan.jankovic@fpsp.edu.rs

3orcid.org/0000-0001-6514-3625, e-mail: milan.radosavljevic@fpsp.edu.rs
} 


\section{УВОД / INTRODUCTION}

Чини се да је туризам у последњој деценији био у налету, како у свету тако и у Србији. Заправо, могло би се рећи, поготову у Србији, с обзиром да је од 2006.године Србија земља без мора. На туристичкој мапи света, Србија се пре свега позиционирала као земља са природним лепотама и великим бројем фестивала. Међу градовима, најпосећенији су Београд и Нови Сад, најпосећенији фестивал је Егзит који се одржава на Петроварадинској тврђави у Новом Саду, а посећене су и српске бање. 2019. година донела је највећи број страних туриста и највећи број ноћења у хотелима, а даље повећање ових показатеља очекивало се и за 2020.годину. Међутим, већ почетком 2020.године постало је очигледно да ове бројке неће бити превазиђене, а како се касније показало ни достигнуте. Туризам и хотелијерство на глобалном нивоу захватила је криза већа него и светски ратови, обарање Светског трговинског центра или пандемије какве су се јављале у последњим деценијама. Из Кине у Европу стигао је вирус чије последице се одражавају и данас. Европске земље попут Холандије, Немачке и Аустрије у потпуној су блокади. Већина земаља у свету у једном тренутку била је у потпуности затворена, па је такав био случај и са Србијом. Вирус COVID-19 у Србију је стигао у марту месецу 2020.године. Убрзо потом уведено је ванредно стање, односно полицијиски час који је ограничавао кретање становништва, а за рад су биле отворене једино апотеке и продавнице прехрамбене робе. Улазак лицима из иностранства био је омогућен једино уз негативан тест на корона вирус, авио саобраћај готово у потпуности је обустављен, те је самим тим у драстичној мери смањен долазак страних туриста. Сличне мере предузеле су и остале државе у којиме становништво Србије традиционално проводи одморе Црна Гора, Грчка, Италија, Шпанија. На тај начин ударац за сектор туризма био је двоструки. Сa једне стране су угрожене туристичке агенције које су реализовале ове аранжмане у иностранству, а са друге стране и домаће туристичке дестинације су бележиле мањи број посетилаца. Последично, и хотелијерство у Србији је претрпело последице смањења броја посетилаца. 2020. годину обележило је путовање унутар граница Србије, међутим овај вид путовања најчешће се одвијао у сопственој режији, што дакле није утицало претерано позитивно на пословање хотела и туристичких агенција. Као и већина других земаља, и Србија је предузела низ мера у циљу помоћи опстанка како приватног сектора у целости, а посебно туризма и хотелијерства. У вези са туризмом и хотелијерст- вом, мере су првенствено биле усмерене на опстанак субјеката који послују у овим гранама, као и очувањем броја запослених на истом или приближно истом нивоу. У наставку рада биће дат преглед свих мера које су до сада предузете од стране Владе Републике Србије и надлежних министарстава. С обзиром да је пандемија још увек актуелна, многе забране још увек су на снази, попут забране окупљања већег броја људи, а што се одражава и на туризам и хотелијерство. Промене у овим секторима су се десиле, у смислу да је дошло до гашења одређеног броја привредних субјеката и смањења броја запослених. Коначан исход примењених мера остаје да се види.

\section{1. УТИЦАЈ COVID-19 НА ТУРИЗАМ И ХОТЕЛИЈЕРСТВО / \\ THE INFLUENCE OF COVID-19 ON TOURISM AND HOTEL INDUSTRY}

Како наводе у Светској туристичкој организацији, 2020. година сматра се најгором годином у историји за туризам, с обзиром да је забележено смањење од 72\% међународних долазака, као и губитак од чак 935 милијарди долара у односу на исти период 2019. године (https://www.unwto.org). Ово је губитак чак десет пута већи од оног забележеног 2009. године током трајања светске економске кризе. Очекивања у вези са повратком на пређашње стање различита су и варирају од потпуно оптимистичних до крајње песимистичких. При томе, очекивања да ће се почетак побољшања десити већ у јулу 2020. године нису остварена, па чак ни она да се то деси на јесен 2020. или почетком децембра. Стога, преостала су очекивања да ће се позитивни помаци десити током 2021. године.

Meре ограничења кретања становништва између различитих земаља узроковале су застој у више сектора, не само у туризму. Први на удару био је сектор саобраћаја, и то пре свега ваздушног, с обзиром да су потребе за њим смањене и то драстично. Опадање активности у туризму и хотелијерству не посматра се само кроз мање приходе или затварање ових објеката, већ је то ланац који укључује и запослене у тим објектима, али и бројне организације повезане са њима (добављаче хране, цвећа, галантерије и слично). Број ноћења у хотелима такође је вишеструко смањен, као и приходи од трговине, приходи угоститељских објеката, многе мале туристичке агенције су потпуно угашене, у питање су доведени и највећи спорстски и културни догађаји. Пандемија светских размера изискује прилагођавање у готово свим областима живота, па је 
такав случај и са туризмом и хотелијерством. Како се наводи на сајту Светског савета за туризам и путовања (енг. World Travel and Tourism Council), као трендови за период опоравка од пандемије COVID-19 наводе се: еволуција потражње, акценат на здравље и хигијену, иновативност и дигитализација и наравно одрживост (https:// wttc.org).

Економски утицај разликује се у гранама индустрије туризма у зависности од низа фактора, укључујући природу туристичке понуде, утицај ограничења путовања на проток посетилаца, обим и сложеност пословања, величину домаћег туристичког тржишта и изложеност међународним тржиштима, као и месту које туризам заузима у привреди (Истраживачки центар Скупштине Црне Горе, 2020). Као што је поменуто у апстракту, последице пандемије COVID-19 разликују се како у односу на различите државе, тако и у односу на различите секторе. По питању утицаја на туризам и хотелијерство појединих земаља, сасвим је очекивано да што је већи допринос ових сектора и њиховог учешћа у привреди то су веће и негативне последице пандемије. Како се види у Регистру туризма Агенције за привредне регистре, од марта 2020. године до 14. јануара 2021. године из регистра је обрисано 149 организатора путовања и 29 посредника (https://www.apr.gov.rs).

Иако се Србија у односу на неке друге дестинације не може сматрати примарно земљом која живи од туризма, претходни период обележио је пораст броја долазака туриста из иностранства, као и пораст броја ноћења. Туризам у Србији, према подацима Републичког завода за статистику, а мерено бројем ноћења, бележи значајнији пораст најпре у периоду од 2005. до 2008. године, док је период између 2011. и 2013. означен као период стагнације. 2014. година је обележила почетак експанзивног раста туристичке активности у Србији, који је трајао до марта 2020. године (Катић и др., 2020). У 2020. години, најзначајнији међугодишњи пад од чак 94,6\% остварен је у априлу, док су у каснијим месецима забележена повећања броја ноћења, али и даље знатно мања него у односу на 2019. годину. У 2019. години по први пут је број ноћења страних туриста био већи од броја ноћења домаћих туриста. Посебно је велики број страних држављана посећивао веће градове, попут Београда и Новог Сада, а значајан број посетилаца био је заинтересован и за српске планине. У прилог томе говоре и следећи показатељи. Према подацима Републичког завода за статистику, у априлу 2019. године у односу на април 2018. године број долазака туриста био је већи за 6,2\%, док је број ноћења био већи за 8,6\% (https://www.stat.gov.rs). И током прва два месеца претходне године забележен је велики пораст броја посета страних туриста (из Русије 65,3\%, Турске 58,5\%, Кине 41,3\% и Грчке 40,7\%), што указује на то да је 2020.година у том погледу могла бити још успешнија од 2019. У наставку 2020.године међутим овај позитивни тренд из добро познатих разлога није настављен. У новембру 2020.године број долазака туриста мањи је за чак $61,3 \%$, а број ноћења мањи је за $46,4 \%$ у односу на новембар 2019. године (https://www. stat.gov.rs).

Пандемија је оставила трага и на хотелијерство и угоститељство. С обзиром да нема долазака туриста из иностранства смањена је и потреба за ноћењем у хотелима. Велики број хотела осим услуга смештаја ослањао се и на приходе остварене од издавања својих сала за догађаје на којима присуствује већи број људи, што је већ годину дана забрањено. Стога, највећи проценат хотела бележи значајно смањење прихода. Како су навели из Пословног удружења хотелско-угоститељске привреде Србије, у јуну 2020.године од 380 хотела отворено је свега њих 112 , уз попуњеност капацитета од свега $10,79 \%$ (https://biznis.rs). У зависности од величине хотела разликују се и фриксни трошкови пословања, али они свакако чине значајан проценат у укупним трошковима. Оптерећење фиксним трошковима постаје још веће уколико хотели не врше своју примарну услугу - пружање услуга смештаја и исхране. Велики број хотела је, поред тога, поседовао и сале за издавање (организаовање прослава, конференција и слично). Ограничавањем броја људи коју могу боравити у затвореном простору, хотели су остали и без могућности стицања прихода по том основу. У случају туристичких агенција, примарни проблем јавио се у вези са аранжманима који су већ били унапред резервисани. Наиме, туристичке агенције послују тако што на жељеним дестинацијама склапају уговоре са тамошњим партнерима (хотелијерима, ресторанима, водичима), за шта најчешће уплаћују новац авансно. Са таласом ширења пандемије корона вируса уследио је и талас отказивања аранжмана. C обзиром на то да је велики број земаља био затворен, реализација није била могућа. Туристичке агенције - посредници или такозвани retailer-i су углавном мала предузећа у породичном власништву (Штетић, Драгићевић, 2011). Ова чињеница је значајна за разумевање ситуације у којој су се ове агенције нашле након наступања епидемије светских размера. Наиме, отказивање преко 90\% аранжмана у сезони за највећи број агенција значио је или смањење 
броја запослених или њихово затварање. Домаћи туризам јесте оживео током 2020. године, али у том случају реч је о готово стопроцентном самосталном организовању, што значи да највећи број посетилаца туристичких дестинација у Србији није користио услуге туристичких агенција. У периоду између јануара и септембра 2020. године најпосећенија су била бањска места, где предњаче Сокобања и Врњачка бања, у којима је било чак 95\% домаћих посетилаца. Осим бања посећене су биле и планине Србије, а међу њима предњаче Златибор и Копаоник. У циљу интензивирања туристичке делатности унутар Србије, Влада је поделила 160.000 ваучера за летовање на дестинацијама у Србији, што је за 60.000 више него у претходним годинама. Такође, праг минималних зарада је повећан, тако да су сада корисници ваучера могли бити појединци са нето зарадом до 70.000 динара.

Према проценама тадашњег министра туризма, Расима Љајића, сектор туризма претрпеће највеће губитке услед пандемије COVID-19, при чему су процене о губицима до 300 милиона евра. Осим великих губитака, регистровано је и повећање броја туристичких агенција које су отишле у стечај, као и повећање броја оних које су прешле у статус мировања. Очекивања Асоцијације туристичких агенција Србије јесте да кризу превазиђе свега 70 агенција од чак 415, а да се број запослених у туристичким агенцијама са 4000 смањи на 1000. Положај туристичких агенција додатно је отежан неопходношћу поседовања банкарске гаранције, чија је цена за мање агенције око 200.000 евра, док за веће износи чак 400000 евра. Како би се превазишли проблеми у вези са тим, Министарство трговине, туризма и телекомуникација предложило је измену правилника којим су смањени лимити покрића гаранција путовања, а смањен је и износ депозита које агенције морају имати на рачуну последњег дана у години. Најмањи лимит за гаранцију путовања је у категорији A10 до 300 путника и са лимитом покрића од 50.000 евра, док је највиши лимит од 400.000 евра у категорији A40 за преко 10.000 путника. Најмањи депозит који агенције према новој уредби морају имати на стању 31.децембра је у категорији A10 и износи 300 евра, а највећи депозит од 3.500 евра морају имати агенције из категорије A40.

2. ФИНАНСИРАЊЕ ПРОЈЕКАТА ПОДРШКЕ ТУРИЗМУ И ХОТЕЛИЈЕРСТВУ I FINANCING OF SUPPORT PROJECTS FOR TOURISM AND HOTEL INDUSTRY

Србија није једина земља која је преузела мере за помоћ угроженим секторима услед пандеми- је ковида. Мере за помоћ туризму и хотелијерству предузеле су и многе европске земље попут: Естоније, Португала, Шведске, Хрватске, Грузије, Италије, Мађарске... Мере предузете у Србији и другим земљама у основи су сличне, међутим свакако постоје одређене специфичности, а оне су пре свега условљене процентом у којем су земље зависне од туризма, те од величине претрпљених губитака, али и од економске снаге ових земаља. Оно што је свакако заједничко за мере предузете у циљу помоћи угроженим секторима, а независно од земље у којој се примењују, јесте да су оне усмерене на одржање ликвидности, давање фринансијских олакшица и грантова приликом одобравања зајмова, свођење стопе отпуштања радника на минимум. Естонија је извршила ребаланс буџета и то тако што је дошло до његовог проширења, од чега је изгласан наменски пакет помоћи од чак 25 милиона евра. Влада Грузије определила се за субвенционисање шестомесечних кредита одобрених малим хотелима, и то чак у износу од $80 \%$. Хрватска је приватне изнајмљиваче преноћишта ослободила плаћања туристичке таксе, и то за целу 2020. годину за помоћне кревете и половине износа за главни кревет и смештајне јединице у камповима и камп-одмориштима. Такође, у 2020. и 2021. години, уређено је да се неће одредити износ укупних прихода који се може користити за трошкове плата запослених. Значајни финансијски подстицај јесте и одобравање бескаматних кредита Хрватске банке за обнову и развој предузетницима у туристичкој делатности у укупном износу од 3341990 евра односно 26 милиона куна. Ова средства намењена су искључиво туристичком сектору, с обзиром да се као корисници могу јавити микро, мали и средњи предузетници који обављају делатности пружања услуга смештаја, припреме и услуживања хране и пића, организовања путовања, изнајмљивања пловних превозних средстава. Рокови отплате кредита су до 5 година, са могућношћу продужења до једне године, при чему одобрени кредити не могу бити нижи од 13.000 евра (100.000 куна). Интересантан је приступ исландске владе, која је фокус у периоду пандемије ставила на инвестициона улагања усмерена на унапређење инфраструктуре, како би се ова острвска земља припремила за период након престанка кризе. У том циљу, одређено је чак 93.988.100 евра, од чега ће највећи део бити усмерен на изградњу инфраструктуре у националним парковима, унапређењу лука, путева, заштиту туристичких локалитета, али и реновирање концертне дворане и конференцијског центра Харпа у Рејкјавику (Истраживачки центар Скуп- 
штине Црне Горе, 2020). У првом скупу мера које је изгласала италијанска влада, мере усмерене на туризам и културу, као и запослене у овим секторима, већ су заузеле своје место. Одређене су посебне надокнаде за запослене у овим секторима, али и подршка компанијама које послују у овим областима у виду обуставе плаћања пореза и доприноса. И у Италији је у великој мери примењен систем ваучера, како би се пре свега растеретио сектор туризма и културе од неопходности моменталне накнаде клијентима услед отказаних путовања, концерата, изложби, представа. Италијанска влада директно је финансирала и запослене у овим секторима и то са по 600 евра надокнаде за март месец, док је пружена и помоћ италијанским авио компанијама од 200 милиона евра. Мађарска, односно њен туристички сектор претрпео је значајне последице услед пандемије, с обзиром да је од 1070 хотела затворено чак 1000, и да је 100.000 људи изгубило посао. Већ приликом предузимања првих мера, мађарска влада је акценат ставила на помоћ туризму. Послодавци су ослобођени плаћања пореза на зараде за 4 месеца почев од марта, осим доприноса за здравствено осигурање, а Влада је преузела 30\% трошкова за плаћање пензијског и здравственог осигурања запослених. Интересантно је да су многе од наведених земаља велики значај придале и маркетингу, као што је то пре свега случај са Исландом и Италијом. Ове мере наведене су како би служиле као добар репер за упоређивање са мерама предузетим од стране Владе Републике Србије.

10. априла Влада Републике Србије усвојила је пакет економских мера у вредности од 608,3 милијарде динара, односно 5,1 милион евра. Како би се успоставио правни оквир и спровео овај вид фринансирања угрожених привредних грана, али и грађана Србије, донете су три Уредбе. Првом Уредбом уређују се пореска политика, као и директна давања приватном сектору. Предвиђено је одлагање обавезе плаћања пореза и доприноса на зараде, тако да су они одложени за 04. јануар 2021. године, а од тог тренутка би се плаћали на рате и без камате. У оквиру пореских олакшица одложено је и плаћање пореза на добит за 2021. годину. Ово није било безусловно, већ је предуслов био да привредни субјекти, у овом случају туристичке агенције и хотели, нису отпустили више од 10\% почевши од 15. марта 2020. године. До 30.06.2020.године, Влада је доделила готовинска давања предузећима и појединцима у износу од 11\% БДП-а (International labour organization, 2020). Око 950 милиона евра одвојено је за субвенције намењене очувању радних места, 620 ми- лиона евра за помоћ грађанима, 58 милиона евра за помоћ пензионерима.

24 милијарде динара предвиђено је за кредитирање ликвидности преко Фонда за развој. Циљ је одржавање текуће ликвидиности и омогућавање набавке обртних средстава, а средства из Фонда намењена су привредним лицима у приватном или задружном власништву, а која обављају пољопривредну, производну, трговинску или услужну делатност. Трећа Уредба Републике Србије односи се на емисију хартија од вредности.

Програми помоћи подразумевали су и директна новчана давања и то у износу минималне нето зараде за запослене. Динамика исплате била је мај, јун и јул, а образац обрачунавања следећи:

\section{број запослених са пуним радним временом Х минимална нето зарада .}

Послодавац је био дужан да поднесе Образац ППП-ПД (Појединачна пореска пријава о обрачунатим порезима и доприносима) за запослене за период за који се наплаћује минимална зарада. Директна давања била су предвиђена и за велика привредна лица која су смањила обим посла, и то у износу од $50 \%$ минималних зарада по запосленом.

Међу првим корацима које је Влада Републике Србије предузела у циљу смањења негативних последица по туристички сектор Србије јесте и доношење Уредбе о понуди заменског путовања за туристичко путовање које је отказано или није реализовано услед болести COVID-19 изазване вирусом SARS-CoV-2 (International labour organization). Наведена Уредба донета је 30. априла 2020. године, а за циљ је имала да се агенције растерете терета повраћаја уплаћених новчаних средстава за путовања која су отказана. У ову групу спадају сва путовања уговорена пре ступања на снагу ванредног стања, односно пре 15.марта, а која су делимично или у потпуности исплаћена туристичким агенцијама. На тај начин омогућено је одржавање ликвидности туристичких агенција. Уредбом је предвиђено да путници могу искористити заменско путовање до 31. децембра 2021. године. На дан доношења уредбе укупна вредност свих резервисаних аранжмана грађана Србије који су на чекању због пандемије је око 150 милиона евра, а највећи део односи се на Грчку, Турску и Египат, а мањи део на Шпанију, Италију, Црну Гору и Бугарску (https://novaekono mija.rs). 
Посебан сет мера био је усмерен на хотелијере. 312 хотела у 68 места у Србији добило је директну помоћ Републике Србије у укупном износу од 10,5 милиона евра. Конкретно, хотелијерима су припадале субвенције од 350 евра по лежају и 150 евра по смештајним јединицама, односно по собама. У случају смањења броја запослених у периоду од 15. августа до 31. децембра 2021. године, хотелијери су губили право на субвенције.

Међу последњим мерама из 2020.године, а које се односе на туризам и угоститељство јесте она од 4.децембра. Тада је Влада Републике Србије донела Уредбу о утврђивању Програма распореда и коришћења субвенција за подршку раду угоститељске и туристичке привреде због потешкоћа у пословању проузрокованих епидемијом болести COVID-19 изазване вирусом SARS-COV-2 (https://www.propisi.net). Овим програмом посебно је предвићена помоћ сектору туризма, и то кроз издвајање 1.980.000.000 динара за исплату минималних зарада за запослене у угоститељству, хотелијерству, туристичким агенцијама и rent-a-car агенцијама.

Још једно од настојања Министарства надлежног за овај сектор јесте и увођење тзв. COVID19 ПДВ-а, односно смањење ПДВ-а са $20 \%$ на $10 \%$ на услуге исхране угоститељству. Ово је пракса коју већ примењују земље у Европи.

С обзиром на чињеницу да су мере борбе против ширења пандемије још увек на снази, не може се добити коначна слика стања у српском туризму и хотелијерству накона пандемије. Оно што је чињеница, јесте да је током 2020.године повећано интересовање за руралним туризмом, те је нешто већи и број регистрованих домаћинстава. Тренутно је на територији Србије око 1000 регистрованих сеоских туристичких домаћинстава. Поред њих, постоје и објекти домаће радиности, као што су апартмани у бањама и на планинама, викендице, а који се од сеоских туристичких домаћинстава разликују по томе што не нуде услуге исхране. Овај сектор туризма у Србији, али и свугде у свету, показао се као више имун на кризу каква је задесила друге секторе туризма, с обзиром да је усмерен на домаће туристе. Што се тиче мера подршке за овај вид туризма, поред оних које су раније описане, присутан је и програм IPARD 2, Mera 7, расписан од стране Министарства пољопривреде. Током 2020. године поднето је око 300 захтева по овом пројекту, а резултат би требао да буде изградња, доградња и опремање стотинак објеката за спровођење руралног туризма на територији читаве Србије. Са друге стране, услед пандемије и пре- усмеравања средстава у друге намене, ове године изостала су средства Министарства пољопривреде за рурални туризам.

\section{ЗАКЉУЧАК / CONCLUSION}

Иако пандемија COVID-19 није прва кризна ситуација која је задесила туризам, свакако је прва која истовремено погађа читаву планету. Пре тога, дешавале су се кризне ситуације, попут 11. септембра и напада на Светски трговински центар, природних непогода или избијања ратних сукоба, али ово је свакако јединствени случај. Након развоја туризма какав је био бележен готово читаве претходне деценије уследио је нагли заокрет. При томе је уочено да су разматране гране, у овом случају туризам и хотелијерство, изложене ризику чије последице могу бити огромне. Са аспекта туризма и хотелијерства, 2020. година свакако ће бити упамћена, с обзиром на потешкоће које су задесиле ове гране. Пандемија је створила структурне штете чије превазилажење захтева еволуцију у овим гранама, а не само настојање да се врати на старо.

Различите државе различито су реаговале на кризу. Поједине европске земље још увек су у тзв. "lockdown"-y - на снази је полицијски час, велики проценат запослених ради од куће, ресторани и кафрићи су затворени, није дозвољен долазак страних туриста у земљу, настава се одвија online. Влада Србије је на препоруку формираног кризног штаба примењивала све ове мере у борби против ширења пандемије. Иако се Србија не ослања на туризам као неке друге земље, ова привредна грана је последњих година бележила значајан пораст. У циљу помоћи секторима туризма и хотелијерства Влада Републике Србије одлучила се за низ мера које су за циљ имале помоћ опстанку појединцима који послују у овим секторима, али и одржавање броја запослених. У том циљу пружена је директна новчана помоћ, али и извршена измена динамике отплате пореских обавеза. Дејство ових мера још увек је на испитивању, с обзиром да је и пандемија још увек на снази, а масовна вакцинација становништва тек је у зачетку. Како показују званични подаци, и поред фринансијске подршке ипак је дошло до затварања одређеног броја туристичких агенција и хотела, као и до смањења броја запослених.

\section{ЛИТЕРATУРA / REFERENCES}

[1] Katić, G., Pavlović, M. Zlatanović, V., Jotev, J. (2020), Trendovi. Republički zavod za statistiku. Beograd. Str. 50. 
[2] International labour organization. (2020), COVID19 i svet rada. Brza procena uticaja na zapošljavanje i mera politike. Beograd. Str. 40.

[3] Istraživački centar Skupštine Crne Gore, (2020), Mere pojedinih zemalja usmerene na oporavak $u$ sektoru turizma usled pandemije COVID-1, Podgorica. Str. 8.

[4] Štetić, S., Dragićević, V. (2011), Evaluacija turističkih agencija u Srbiji. Ekonomske teme (Niš), 49 (1), str. 72.

[5] https://www.unwto.org/news/tourism-back-to1990-levels-as-arrivals-fall-by-more-than-70 (17.01.2021).

[6] https://wttc.org/Research/To-Recovery-Beyond (17.01.2021)

[7] https://www.apr.gov.rs/registri/turizam.2240.html (26.01.2021)

[8] https://www.stat.gov.rs/sr-latn/vesti/20190530turisti\%C4\%8Dki-promet-april-2019/ (17.01.2021).
[9] https://www.stat.gov.rs/sr-latn/vesti/20201230turisticki-promet-novembar-2020/?s=2202 (17.01.2021).

[10] https://biznis.rs/vesti/u-srbiji-rezervisano-samoosam-odsto-kapaciteta-hotela-udruzenje-horespoziva-gradjane-da-odmor-provedu-u-zemlji/ (30.01.2021).

[11] https://www.pravnoinformacionisistem.rs/SIGlasni kPortal/eli/rep/sgrs/vlada/uredba (24.01.2021)

[12] https://novaekonomija.rs/vesti-izzemlje/zamrznuti-turisti\%C4\%8Dkiaran\%C5\%BEmani-gra\%C4\%91ana-srbije-od150-miliona-evra (24.01.2021).

[13] https://www.propisi.net/uredba-o-utvrdjivanjuprograma-rasporeda-i-koriscenja-subvencija-zapodrsku-radu-ugostiteljske-i-turisticke-privredezbog-poteskoca-u-poslovanju-prouzrokovanihepidemijom-bolesti-covid-19-izazvane-vir/ (26.01.2021). 